\title{
Analysis of risk factors of recurring non-specific low back pain with particular emphasis on "new" predictive factors
}

\author{
ANNA CITKO ${ }^{1, \text { A, c-F }}$, STANISŁAW GÓRSKI², c-E , LUDMIŁA MARCINOWICZ³, в, F, ANNA GÓRSKA 1, A, в \\ ${ }^{1}$ Department of Family Medicine and Community Nursing, Medical University of Bialystok, Poland \\ ${ }^{2}$ Department of Medical Didactics, Jagiellonian University Medical College, Cracow, Poland \\ ${ }^{3}$ Department of Primary Health Care, Medical University of Bialystok, Poland
}

A - Study Design, B - Data Collection, C - Statistical Analysis, D - Data Interpretation, E - Manuscript Preparation, F - Literature Search, G - Funds Collection

Summary Background. Non-specific low back pain (NSLBP) is one of the most frequent causes of medical consultations. The recurrence rate is high and estimated to be within the range from $25 \%$ to $70 \%$ in different populations. Currently, the contribution of various predictive factors of NSLBP is being discussed. What seems to be interesting are studies on the impact of chronic diseases on the occurrence of NSLBP.

Objectives. The purpose of this paper is to assess the frequency and analyse the risk factors of recurring NSLBP with a particular emphasis on "new" predictive factors.

Material and methods. 609 people (medical staff) aged 30-55 participated in the study. The study was conducted by means of a random employee survey supervised by the authors of this paper.

Results. 253 subjects (41.54\%) complained of recurring NSLBP. Recurrences of NSLBP occurred in $48.34 \%$ of the respondents aged between 30 and 40 . In the multivariate logistic regression, the following factors had, inter alia, a significant influence on the occurrence of recurring NSLBP: excessive coffee consumption ( $\geq 6$ cups a day), smoking, hyperlipidemia, occurrence of low back pain in the respondent's family $(p<0.001 ; p<0.001 ; p<0.01 ; p<0.01$, respectively).

Conclusions. 1. Prevention measures aimed at prevention of NSLBP recurrences should include young adults. 2 . An important element in the diagnostic and therapeutic process is a holistic approach of the family doctor to a patient with recurring NSLBP, taking into account not only the nature of the professional work connected with biomechanical load on the spine, but also the patient's lifestyle and their concurrent diseases. 3. It is necessary to conduct further research on the impact of chronic diseases on the occurrence of recurring NSLBP. Evidence showing the existence of new predictive factors may be a basis for the implementation of better prevention strategies aimed at the prevention of NSLBP recurrence.

Key words: predictors, low back pain, recurring.

Citko A, Górski S, Marcinowicz L, Górska A. Analysis of risk factors of recurring non-specific low back pain with particular emphasis on "new" predictive factors. Fam Med Prim Care Rev 2017; 19(3): 201-208, doi: https://doi.org/10.5114/fmpcr.2017.69275.

\section{Background}

Low back pain is an important health and social issue of modern times [1-5]. It is estimated that around $75-85 \%$ of all people experience lower back pain at some point in their lives. The annual incidence of lower back pain ranges from $15 \%$ to $20 \%$ in the United States and from $25 \%$ to $45 \%$ in Europe [5]. The results of the 2007 "Eurobarometer" study indicate that $39 \%$ of Polish respondents reported experiencing pain which limited their daily activities. The pain was most often located in the area of the lumbosacral spine. As many as $11 \%$ of respondents pointed to that part of the body. According to a survey conducted in 2014 by the European Health Interview Survey (EHIS), 59\% of adults declared a health condition or chronic illness. The most common complaint was lower back pain. As many as $28.4 \%$ of interviewed women and $21.2 \%$ of men aged 15 and over reported the occurrence of this type of pain [3].

Moreover, the authors are concerned about the fact that lower back pain is becoming increasingly a medical problem not only among young people, but also among children. It is currently emphasized that the incidence among children and adolescents is similar to that among adults $[5,6]$.

As a result, lower back pain was ranked first in the list of the most common causes of disability according to YLD (Years Lived with Disability) [7].
In the vast majority of people (85-90\%) with low back pain, no structural pathology which would undoubtedly be responsible for the symptoms can be identified. In this case we are dealing with non-specific low back pain (NSLBP).

Non-specific low back pain is one of the most common causes of medical consultation. The recurrence rate is high and is estimated to range from $25 \%$ to $75 \%$ in different populations. It was found that disability caused by lower back pain was longer in recurrent pain compared to the first episode $[4,5]$.

The relationship between risk factors and NSLBP is probabilistic and not deterministic. This means that a person with risk factors is more likely to develop symptoms in the future, but this is not unavoidable and that person may remain free of symptoms [4].

Researchers are looking for evidence of the impact of various predictive factors on the onset of NSLBP. A significant part of published research focuses on the impact of NSLBP on factors such as: individual factors (age, gender, weight, overweight or obesity, sedentary lifestyle), morphological factors and psychosocial factors. Authors' opinions regarding the relationship between risk factors and NSLBP are varied [4, 8, 9]. For example, some authors suggest that there is a U-shaped relationship between biomechanical load and the incidence of lower back pain. This means that both physical inactivity and excessive physical activity predispose patients to NSLBP. The occurrence of such 
a dependence is explained by the ability of the spine tissues to adapt to increased as well as reduced biomechanical loads. Heneweer et al. demonstrated the existence of such a relationship in a group of 3664 people aged over 25 years among Dutch citizens [10]. Heuch et al., who had studied 9616 women and 8452 men, among Norwegian citizens, came to different conclusions [11]. Fewer reports concern the impact of smoking on the onset of NSLBP $[8,12,13]$.

There are no reports on the effects of lifestyle factors, such as consumption (excessive coffee consumption, alcohol abuse), insufficient sleep, abnormal nutritional habits involving eating too little and/or lack of regularity in eating, on the incidence of NSLBP. There are also no reports on the relationship between the place of residence (city, village) and NSLBP. A detailed analysis of the impact of various lifestyle factors on NSLBP can help identify "new" predictors and implement better preventive strategies.

It is not possible to rule out the existence of hereditary tendencies for intervertebral disc disease, which predisposes patients to NSLBP. However, there is no obvious link to a specific illness, as in other diseases (diabetes, peptic ulcer) [14].

The studies on the effect of chronic diseases on the incidence of NSLBP seem interesting. Some authors claim that depression and anxiety disorders are the best-studied risk factors for NSLBP, and patients who complain of these types of pain score significantly higher in tests for drug disorders, depression and emotional lability $[4,14]$. Up until now, there have been isolated English-language reports suggesting NSLBP association with hyperlipidemia, cardiovascular disease, type 2 diabetes, asthma, allergy or urinary incontinence [15-22].

It should be noted that some of the studies on the assessment of the impact of various risk factors on NSLBP do not distinguish between certain types of pain (no distinction between the first pain episode, episodic pain and recurrent pain), but instead focus on acute, subacute and chronic pain [4]. The high prevalence of NSLBP, high rate of recurrence, and the resulting social and economic burden, as well as the contradictory opinions of authors on the significance of the different predictors in NSLBP, the emerging "new" predictors for NSLBP, encourage further research. It is therefore justified to conduct such a multifaceted analysis.

\section{Objectives}

On the one hand, the aim of the study was to assess the incidence of recurrent NSLBP (including in younger and older age groups). On the other hand, the impact of various factors on recurrent NSLBP was investigated, with particular emphasis on "new" predictors.

\section{Material and methods}

A group of 609 randomly selected people (medical staff) participated in the study. They lived in Podlaskie province, and their age ranged from 30 to 60 years (the average age was 40.99 \pm 6.66 years). In total, 324 nurses (53.2\%) and 285 paramedics $(46.8 \%)$ were included in the study. Among the subjects, there were 302 people aged $30-40(49.6 \%)$ and 307 people aged $41-$ $-60(50.4 \%)$. As far as the sex of the participants was concerned, women constituted 59.44\% (362 people), men - 40.56\% (247 people). As far as the value of the body mass index (BMI) was concerned, it was established that 314 (51.56\%) people had correct body mass $\left(\mathrm{BMI}=18.5-24.99 \mathrm{~kg} / \mathrm{m}^{2}\right)$ while $295(48.44 \%)$ subjects were overweight $\left(\mathrm{BMI}=25-29.99 \mathrm{~kg} / \mathrm{m}^{2}\right)$ or obese $\left(\mathrm{BMI} \geq 30 \mathrm{~kg} / \mathrm{m}^{2}\right)$. Detailed characteristics of the study group are shown in Table 1.

The study was conducted by means of a random employee survey supervised by the researchers, i.e. the authors of this paper.

\begin{tabular}{|l|l|l|}
\hline \multicolumn{3}{|l|}{ Table 1. Characteristics of the study group } \\
\hline Variable* & Median & Min-Max \\
\hline Age (years) & 41 & $30-55$ \\
\hline Height $(\mathrm{cm})$ & 170 & $150-201$ \\
\hline Body weight $(\mathrm{kg})$ & 72 & $46-110$ \\
\hline BMI $\left(\mathrm{kg} / \mathrm{m}^{2}\right)$ & 24.8 & $17.96-38.46$ \\
\hline
\end{tabular}

*Due to the deviation from the normal distribution of variables presented in the table, median and minimum-maximum values are given ( $p<$ 0.05; Shapiro-Wilk test).

The following types of questionnaires were used:

1. A questionnaire partly based on the Standardised Nordic Questionnaire (Nordic Musculoskeletal Questionnaire) - it contains questions concerning the frequency of musculoskeletal pain occurrence (1-2 times in the last 12 months, $\geq 3$ times in the last 12 months, pain present continuously for at least the last 12 weeks) within 9 anatomical regions: neck/nape, shoulders, upper back, lower back, elbows, wrists/hands, hips/thighs, knees, ankles/feet. The respondents were also presented with a task which required them to mark in a picture the place in which the pain (if any) was present [23].

2. A questionnaire on pain in the lumbosacral region validated as per IEA's (International Epidemiological Association) guidelines - it contains questions concerning the occurrence of pain in the lumbosacral region of the spine, the length of the episode, chronic diseases, medical diagnosis of low back pain, concurrent faulty posture and possible malnourishment/sleep deficit. This questionnaire also includes questions concerning basic "red flags" which may constitute a sign of pain of a specific origin in the lumbosacral region [24].

3. A questionnaire developed by the authors concerning sociodemographic data, selected elements of lifestyle (smoking, coffee consumption) as well as a full-scale interview within the scope of chronic diseases in the respondents and their families.

4. The short version of the International Physical Activity Questionnaire (IPAQ) - questions included in it concern the frequency and time of physical activity with high, moderate and low intensity, lasting continuously for 10 minutes [25]. The percentage of sufficiently active subjects was established on the basis of the estimated caloric cost of physical activity, using the assumptions of Paffenbarger et al. [26].

The following respondents were excluded from the study: those undergoing treatment due to autoimmune disease/cancer, people with a history of osteoporotic fracture, respondents who had suffered injuries within 3 months preceding completion of the questionnaire, and respondents who had shown symptoms which could presumably constitute the so-called "red flags" that signal specific low back pain $[4,5]$.

An acute pain episode which had occurred $\geq 3$ times in the last 12 months was considered "recurring" low back pain [27].

The number of hours of sleep less than 7 hours a day was considered a sleep deficit, whereas $\geq 6$ cups of coffee a day were regarded as excessive coffee consumption $[28,29]$.

Answering the question about concurrent diseases, the respondents mentioned: cardiovascular diseases, excluding hypertension (arrhythmia, coronary heart disease, cardiomyopathy), thyroid diseases (hypothyroidism, hyperthyroidism, nodular goiter), skin diseases (acne vulgaris, albinism, atopic dermatitis, contact eczema), eye diseases (myopia, hyperopia, astigmatism, dry eye syndrome), gastrointestinal diseases (gastro-oesophageal reflux, gastric and/or duodenal ulcer, irritable bowel syndrome, hiatus hernia, diverticulosis, hepatic steatosis), urogenital system diseases (prostatic hyperplasia, nephrolithiasis, stress incontinence, endometriosis), respiratory system diseases (chronic obstructive lung disease, bronchiectasis, asth- 
ma), otolaryngological diseases (nasal polyps, chronic sinusitis, chronic rhinitis, chronic laryngitis).

In the course of the research, a database of variables was created, containing statements, opinions and evaluations of respondents, enabling the use of computational techniques. Statistical analysis began with substantive and logical control of the collected data. In the first stage, the conformity of the tested continuous variables with the Gaussian distribution was verified. In all cases, the Shapiro-Wilk test was performed and the normalization hypothesis was rejected. For this reason, nonparametric tests were used in further analysis. In the case of quantitative variables, the Mann-Whitney $U$ test was used. The chi-square test was used to estimate the relationships between qualitative variables. Due to the presence of dichotomous variables among the analysed variables, univariate and multivariate logistic regression analysis was employed. This was aimed at eliminating the interfering influence of the various independent variables analysed. The statistical significance level was taken to be $p<$ 0.05. The statistical analysis was conducted using STATA/1.C 12.1 software developed by Stata Corp, LP, Texas, USA.

In order to conduct the study, approval was obtained from the Bioethics Commission at the Medical University in Białystok.

\section{Results}

253 people (41.54\%) complained of recurring NSLBP. In the group of people aged 30-40, recurrences of NSLBP were present in 146 people (48.34\%), in the group of older respondents - in 107 people (34.85\%); this result proved to be statistically significant $(p<0.001)$. In the univariate logistic regression model (in the group of people aged 30-40) the chance of occurrence of recurring NSLBP was $79 \%$ higher compared with the group of people aged 41-60 (OR 1.79; 95\% Cl: 1.292-2.479; $p<0.001$ ).

The assessment of the occurrence of the investigated potential predictive factors of recurring NSLBP in the entire investigated population (quantitative distribution) and within the group of people with recurring NSLBP (quantitative and percentage distribution relative to the total number of respondents) is shown in Table 2.

\begin{tabular}{|c|c|c|}
\hline Predictive factor & $\begin{array}{l}\text { Total number } \\
\text { of respondents } \\
\text { who showed } \\
\text { a given predic- } \\
\text { tive factor } \\
n\end{array}$ & $\begin{array}{l}\text { Respondents } \\
\text { with recurring } \\
\text { rachialgia who } \\
\text { showed a given } \\
\text { predictive factor } \\
n(\%)\end{array}$ \\
\hline Overweight or obesity & 298 & $140(53.336)$ \\
\hline $\begin{array}{l}\text { Practising the profession of } \\
\text { paramedic }\end{array}$ & 285 & $134(52.964)$ \\
\hline Smoking & 370 & $214(84.585)$ \\
\hline $\begin{array}{l}\text { Excessive coffee consump- } \\
\text { tion ( } \geq 6 \text { cups a day) }\end{array}$ & 98 & $87(34.387)$ \\
\hline $\begin{array}{l}\text { Incorrect eating behaviour } \\
\text { consisting in eating too few } \\
\text { meals and/or lack of regular- } \\
\text { ity in eating meals }\end{array}$ & 156 & $48(18.972)$ \\
\hline Sedentary lifestyle & 302 & $171(67.589)$ \\
\hline $\begin{array}{l}\text { Insufficient number of hours } \\
\text { of sleep ( }<7 \text { hours a day) }\end{array}$ & 311 & $41(16.206)$ \\
\hline $\begin{array}{l}\text { Village as the place of } \\
\text { residence }\end{array}$ & 85 & $41(16.206)$ \\
\hline $\begin{array}{l}\text { Low self-assessment of the } \\
\text { state of health }\end{array}$ & 84 & $26(10.277)$ \\
\hline
\end{tabular}

\begin{tabular}{|c|c|c|}
\hline $\begin{array}{l}\text { Recurring or chronic neck } \\
\text { pain }\end{array}$ & 371 & $198(78.261)$ \\
\hline $\begin{array}{l}\text { Recurring or chronic upper } \\
\text { back pain }\end{array}$ & 112 & $45(17.787)$ \\
\hline $\begin{array}{l}\text { Recurring or chronic pain in } \\
\text { the upper limbs, excluding } \\
\text { hands }\end{array}$ & 23 & $4(1.581)$ \\
\hline $\begin{array}{l}\text { Recurring or chronic pain in } \\
\text { the lower limbs, excluding } \\
\text { feet }\end{array}$ & 60 & $34(13.439)$ \\
\hline $\begin{array}{l}\text { Recurring or chronic pain in } \\
\text { the wrists/hands }\end{array}$ & 55 & $16(6.324)$ \\
\hline $\begin{array}{l}\text { Recurring or chronic pain in } \\
\text { the feet }\end{array}$ & 22 & $22(2.372)$ \\
\hline $\begin{array}{l}\text { Lumbosacral degenerative } \\
\text { disease }\end{array}$ & 281 & $164(64.822)$ \\
\hline Scoliosis & 108 & $42(16.601)$ \\
\hline $\begin{array}{l}\text { Faulty posture, excluding } \\
\text { scoliosis }\end{array}$ & 88 & $43(16.996)$ \\
\hline Hyperlipidemia & 45 & $31(12.253)$ \\
\hline Hypertension & 34 & $3(1.186)$ \\
\hline $\begin{array}{l}\text { Cardiovascular diseases, } \\
\text { excluding hypertension }\end{array}$ & 47 & $24(9.486)$ \\
\hline Thyroid diseases & 51 & $12(0.743)$ \\
\hline Skin diseases & 10 & $4(1.581)$ \\
\hline Eye diseases & 32 & $6(2.372)$ \\
\hline Gastrointestinal diseases & 69 & $19(7.510)$ \\
\hline Urogenital system diseases & 62 & $19(7.510)$ \\
\hline Allergies & 54 & $31(12.253)$ \\
\hline Respiratory system diseases & 43 & $12(4.743)$ \\
\hline Type 2 diabetes & 58 & $36(22.925)$ \\
\hline Otolaryngological diseases & 11 & $2(0.791)$ \\
\hline $\begin{array}{l}\text { Depression and/or anxiety } \\
\text { disorders }\end{array}$ & 28 & $13(5.138)$ \\
\hline $\begin{array}{l}\text { Chronic fatigue syndrome } \\
\text { (persistence of fatigue symp- } \\
\text { toms for over } 3 \text { months) }\end{array}$ & 144 & $52(20.553)$ \\
\hline $\begin{array}{l}\text { Occurrence of low back pain } \\
\text { in the respondent's family }\end{array}$ & 145 & $89(35.178)$ \\
\hline
\end{tabular}

The results of univariate and multivariate logistic regression analysis of the impact of individual variables on the occurrence of recurring NSLBP are presented in Tables 2 and 3. In the univariate logistic regression, the chance of the occurrence of recurring rachialgia was increased by the following: excessive coffee consumption ( $\geq 6$ cups a day) (over 16 times), smoking (7 times), recurring or chronic neck pain (over 3 times), lumbosacral degenerative disease (over 3 times), sedentary lifestyle (over 3 times), hyperlipidemia (over 3 times), occurrence of low back pain in the respondent's family (over 2 times), type 2 diabetes (over 2 times), allergies (2 times), recurring or chronic pain in the upper limbs, excluding hands (almost 2 times), overweight or obesity (1.6 times), practising the profession of paramedic (1.5 times); these results proved to be statistically significant $(p<0.001 ; p<0.001 ; p<0.001 ; p<0.001 ; p<0.001$; $p<0.001 ; p<0.001 ; p=0.001 ; p<0.05 ; p<0.01 ; p<0.01$; $p=0.01$, respectively). In the analysed model, the chance of the occurrence of recurring NSLBP decreased by $4.8 \%$ with each subsequent year of life. This result proved to be statistically significant $(p<0.001)$ (Table 2$)$. In the univariate logistic regression model, tall stature $(>170 \mathrm{~cm}$ in women and $>180 \mathrm{~cm}$ in men) did not have any influence on the occurrence of recurring NSLBP (OR $=0.912 ; 95 \% \mathrm{Cl}: 0.626-1.331)$. This result proved to be statistically insignificant $(p=0.634)$. In the multivariate logis- 
tic regression model, which took into account the concurrent impact of all variables, the probability of the occurrence of recurring NSLBP was increased by the following: excessive coffee consumption ( $\geq 6$ cups a day) (almost 27 times), lumbosacral degenerative disease (almost 17 times), depression and/or anxiety disorders (over 7 times), smoking (7 times), sedentary lifestyle (over 4 times), occurrence of low back pain in the respondent's family (3 times), recurring or chronic neck pain (almost 3 times); these results proved to be statistically significant $(p<0.001$; $p<0.001 ; p<0.05 ; p<0.001 ; p<0.001 ; p<0.01$, respectively).

\begin{tabular}{|c|c|c|c|}
\hline Predictive factor & OR & $\begin{array}{l}95 \% \text { confidence } \\
\text { interval for OR }\end{array}$ & $p$ \\
\hline Age [years] & 0.952 & $0.929-0.976$ & $<0.001$ \\
\hline Height $[\mathrm{cm}]$ & 1.013 & $0.995-1.03$ & 0.162 \\
\hline Body weight $[\mathrm{kg}]$ & 1.008 & $0.995-1.021$ & 0.24 \\
\hline Overweight or obesity & 1.588 & $1.148-2.197$ & 0.005 \\
\hline Practising the profession of paramedic & 1.529 & $1.105-2.114$ & 0.01 \\
\hline Smoking & 7.035 & $4.714-10.498$ & $<0.001$ \\
\hline Excessive coffee consumption ( $\geq 6$ cups a day) & 16.438 & $8.547-31.611$ & $<0.001$ \\
\hline $\begin{array}{l}\text { Incorrect eating behaviour consisting in eating too few meals and/or lack } \\
\text { of regularity in eating meals }\end{array}$ & 0.538 & $0.365-0.792$ & 0.002 \\
\hline Sedentary lifestyle & 3.582 & $2.549-5.033$ & $<0.001$ \\
\hline Insufficient number of hours of sleep ( $<7$ hours a day) & 0.062 & $0.041-0.093$ & $<0.001$ \\
\hline Village as the place of residence & 1.371 & $0.866-2.172$ & 0.178 \\
\hline Low self-assessment of the state of health & 0.588 & $0.359-0.964$ & 0.035 \\
\hline Recurring or chronic neck pain & 3.808 & $2.646-5.48$ & $<0.001$ \\
\hline Recurring or chronic upper back pain & 0.933 & $0.615-1.417$ & 0.746 \\
\hline Recurring or chronic pain in the upper limbs, excluding hands & 0.285 & $0.096-0.848$ & 0.024 \\
\hline Recurring or chronic pain in the lower limbs, excluding feet & 1.97 & $1.15-3.376$ & 0.014 \\
\hline Recurring or chronic pain in the wrists/hands & 0.549 & $0.299-1.006$ & 0.052 \\
\hline Recurring or chronic pain in the feet & 0.516 & $0.199-1.338$ & 0.174 \\
\hline Lumbosacral degenerative disease & 3.764 & $2.68-5.288$ & $<0.001$ \\
\hline Scoliosis & 0.875 & $0.571-1.339$ & 0.537 \\
\hline Faulty posture, excluding scoliosis & 1.415 & $0.899-2.226$ & 0.133 \\
\hline Hyperlipidemia & 3.411 & $1.775-6.556$ & $<0.001$ \\
\hline Hypertension & 0.126 & $0.038-0.416$ & 0.001 \\
\hline Cardiovascular diseases, excluding hypertension & 1.517 & $0.836-2.754$ & 0.17 \\
\hline Thyroid diseases & 0.405 & $0.207-0.79$ & 0.008 \\
\hline Skin diseases & 0.937 & $0.262-3.355$ & 0.92 \\
\hline Eye diseases & 0.308 & $0.125-0.761$ & 0.011 \\
\hline Gastrointestinal diseases & 0.497 & $0.285-0.866$ & 0.014 \\
\hline Urogenital system diseases & 0.591 & $0.336-1.041$ & 0.069 \\
\hline Allergies & 2.022 & $1.149-3.559$ & 0.015 \\
\hline Respiratory system diseases & 0.522 & $0.263-1.038$ & 0.064 \\
\hline Type 2 diabetes & 2.519 & $1.443-4.397$ & 0.001 \\
\hline Otolaryngological diseases & 0.307 & $0.066-1.434$ & 0.133 \\
\hline Depression and/or anxiety disorders & 1.231 & $0.575-2.635$ & 0.592 \\
\hline $\begin{array}{l}\text { Chronic fatigue syndrome (persistence of symptoms of fatigue for over } 3 \\
\text { months) }\end{array}$ & 0.742 & $0.504-1.093$ & 0.131 \\
\hline Occurrence of low back pain in the respondent's family & 2.907 & $1.979-4.271$ & $<0.001$ \\
\hline
\end{tabular}

$\mathrm{OR}$ - odds ratio.

\begin{tabular}{|l|l|l|l|}
\hline \multicolumn{2}{|l|}{ Table 4. Results of multivariate logistic regression analysis of potential predictive factors of recurring NSLBP } \\
\hline Predictive factor & OR & $\begin{array}{l}\text { 95\% confidence } \\
\text { interval for OR }\end{array}$ & $\boldsymbol{p}$ \\
\hline Age [years] & 0.874 & $0.818-0.934$ & $<0.001$ \\
\hline Height [cm] & 1.113 & $1.044-1.186$ & 0.001 \\
\hline Body weight [kg] & 0.907 & $0.855-0.963$ & 0.001 \\
\hline Overweight or obesity & 3.694 & $1.179-11.573$ & 0.025 \\
\hline Practising the profession of paramedic & 1.723 & $0.73-4.068$ & 0.214 \\
\hline Smoking & 7.02 & $3.457-14.254$ & $<0.001$ \\
\hline
\end{tabular}




\begin{tabular}{|c|c|c|c|}
\hline Predictive factor & OR & $\begin{array}{l}95 \% \text { confidence } \\
\text { interval for OR }\end{array}$ & $p$ \\
\hline Excessive coffee consumption ( $\geq 6$ cups a day) & 26.938 & $8.874-81.772$ & $<0.001$ \\
\hline $\begin{array}{l}\text { Incorrect eating behaviour consisting in eating too few meals and/or lack } \\
\text { of regularity in eating meals }\end{array}$ & 0.372 & $0.149-0.929$ & 0.034 \\
\hline Sedentary lifestyle & 4.247 & $1.902-9.484$ & $<0.001$ \\
\hline Insufficient number of hours of sleep ( $<7$ hours a day) & 0.122 & $0.058-0.259$ & $<0.001$ \\
\hline Village as the place of residence & 1.887 & $0.758-4.699$ & 0.173 \\
\hline Low self-assessment of the state of health & 1.523 & $0.438-5.294$ & 0.508 \\
\hline Recurring or chronic neck pain & 2.815 & $1.424-5.564$ & 0.003 \\
\hline Recurring or chronic upper back pain & 0.39 & $0.164-0.928$ & 0.033 \\
\hline Recurring or chronic pain in the upper limbs, excluding hands & 0.107 & $0.016-0.719$ & 0.021 \\
\hline Recurring or chronic pain in the lower limbs, excluding feet & 1.413 & $0.488-4.096$ & 0.524 \\
\hline Recurring or chronic pain in the wrists/hands & 2.411 & $0.578-10.063$ & 0.227 \\
\hline Recurring or chronic pain in the feet & 0.247 & $0.028-2.212$ & 0.211 \\
\hline Lumbosacral degenerative disease & 16.791 & $6.747-41.79$ & $<0.001$ \\
\hline Scoliosis & 0.456 & $0.197-1.056$ & 0.067 \\
\hline Faulty posture, excluding scoliosis & 0.644 & $0.244-1.702$ & 0.375 \\
\hline Hyperlipidemia & 8.494 & $1.952-36.957$ & 0.004 \\
\hline Hypertension & 0.061 & $0.009-0.413$ & 0.004 \\
\hline Cardiovascular diseases, excluding hypertension & 1.343 & $0.3-6.005$ & 0.699 \\
\hline Thyroid diseases & 0.506 & $0.08-3,195$ & 0.468 \\
\hline Skin diseases & 0.691 & $0.06-8.007$ & 0.768 \\
\hline Eye diseases & 0.119 & $0.018-0.788$ & 0.027 \\
\hline Gastrointestinal diseases & 0.805 & $0.25-2.593$ & 0.716 \\
\hline Urogenital system diseases & 0.48 & $0.162-1.424$ & 0.186 \\
\hline Allergies & 1.335 & $0.398-4.481$ & 0.64 \\
\hline Respiratory system diseases & 0.895 & $0.136-5.901$ & 0.908 \\
\hline Type 2 diabetes & 2.959 & $0.907-9.652$ & 0.072 \\
\hline Otolaryngological diseases & 1.46 & 0.099-21.561 & 0.783 \\
\hline Depression and/or anxiety disorders & 7.403 & $1.154-47.501$ & 0.035 \\
\hline $\begin{array}{l}\text { Chronic fatigue syndrome (persistence of symptoms of fatigue for over } 3 \\
\text { months) }\end{array}$ & 1.339 & $0.508-3.532$ & 0.555 \\
\hline Occurrence of low back pain in the respondent's family & 3.016 & $1.371-6.634$ & 0.006 \\
\hline
\end{tabular}

OR - odds ratio.

\section{Discussion}

What has been emphasised in reports from recent years is the fact of the more and more frequently occurrence of NSLBP in young and middle-aged people. It has been proven that as many as $2 / 3$ of people aged 40 or less have had at least one low back pain incident, and $60 \%$ of them experience recurrence of pain in the same year [30]. A previous lumbosacral pain episode is definitely the strongest sign of lumbar pain $[4,5]$.

This fact was corroborated by the results of our study. In the group of respondents aged 30-40, recurring NSLBP was present in almost a half of the subjects (48.34\%); this result proved to be statistically significant $(p<0.001)$. Apart from the above, in comparison with the respondents aged 41-55, the chance of the occurrence of recurring NSLBP was $79 \%$ higher in the younger respondents $(\mathrm{OR}=1.79 ; p<0.001)$. Therefore, it appears that prevention measures aimed at the prevention of recurrences of NSLBP should also include young adults.

Non-specific low back pain may originate from parts of bones, joints, ligaments, muscles and nerves, or its aetiology may be psychogenic in nature [31].

The results of our study indicated that people declaring consumption of at least 6 cups of coffee a day, in the multivariate logistic regression model, complained of recurrences of NSLBP 27 times more frequently $(\mathrm{OR}=26.938 ; p<0.001)$ in comparison with the other respondents (Table 4). $25 \%$ of the total amount of magnesium is stored in muscles. Its deficiency, especially in the case of hard physical effort, may show as excessive, painful contraction of the extensor muscles of the spine and lumbar muscles [31, 32]. A consequence of magnesium deficiency is a worse general state of health of the organism, also including the musculoskeletal system. It becomes more susceptible to overloading civilisation factors, which in turn may lead to the development of degenerative changes and result in pain [33].

Smoking is hypothetically a potential NSLBP risk factor. It is known that it intensifies oxidative stress. The function of oxygen free radicals includes the induction of apoptosis, as well as the inactivation of proteinase inhibitors, which intensifies their proteolytic action on tissues, causing collagen degradation and disruption in the synthesis of proteoglycan proteins of the main components of the nucleus pulposus and annulus fibrosus. This results in earlier degeneration of intervertebral discs in the lower back [33,34]. It is estimated that smoking constitutes the cause of degeneration of intervertebral discs in approx. $2 \%$ of cases [7]. Apart from the above, smoking addiction may impair the efficiency of muscles cells of the spinal column. Furthermore, a smoker's cough may lead to increased pressure in the vertebral canal and thus cause low back pain [32]. Taking into 
account the results of our study, smoking increased the probability of the occurrence of NSLBP in the multivariate logistic regression model by 7 times (OR $=7.02 ; p<0.001$ ) (Table 4). Noll et al. came to similar conclusions. In a group of 251 athletes from Brazil, smoking was a predictive factor of the occurrence of a low back pain incident [12]. Nuwayhid et al. examined a group of 214 fire-fighters from New York. In people who admitted that they smoked, the probability of the occurrence of low back pain was 13 times higher [13].

What seems to be of interest are the reports of some researchers who prove that hyperlipidemia, which is one of the risk factors of atherosclerosis, may be connected with the occurrence of NSLBP. They explain this by the negative impact of atherosclerotic changes in lumbar arteries or in the region of the abdominal aorta on the supply of nutrients to the intervertebral disc, which may lead to its degeneration [14]. On the basis of a review of 179 original papers published in the Medline database since October 2008, Kauppila et al. proved that calcification in the wall of the abdominal aorta and lumbar arteries led to the occurrence of low back discopathy. They also proved the existence of a relationship between high total cholesterol level and the occurrence of a low back pain incident [17]. Next, Hangai et al. proved that high total cholesterol level was closely related to the degeneration of discs in the lumbosacral section of the spine [35]. Studies conducted among the Finnish population also showed the existence of a relationship between high total cholesterol/triglycerides level and an increased risk of the occurrence of a low back pain incident [19]. However, Kostova and Koleva did not confirm the relationship between the occurrence of hypercholesterolemia and pain in the lumbosacral section of the spine [36].

Musculoskeletal disorders are among the potential side effects of the actions of statins, i.e. the most frequently used hypolipidemic (lipid-lowering) drugs. Pain is present in large muscle groups, including the back muscles. Typically, it appears within 4-6 weeks from the beginning of treatment, although it can also recur after many weeks or years of therapy [37].

The results of our study did not allow a clear assessment of the impact of hyperlipidemia on the occurrence of NSLBP, since we had used the interview data as the basis of the analysis, and not the research results. Nevertheless, we established in the multivariate logistic regression model that the chance of the occurrence of recurring NSLBP in the group of people with hyperlipidemia was 8 times greater compared with the other respondents (OR $=8.494 ; p<0.01$ ) (Table 4$)$.

Some authors claim that type 2 diabetes may lead to earlier degeneration of intervertebral discs, inter alia, in the lumbosacral section of the spine. The process of so-called glycation takes place in the course of this disease. It involves the non-enzymatic modification of proteins by glucose, fructose, as well as other sugars and carbonyl compounds, including reactive short-chain alpha-oxoaldehydes. This leads to the creation of advanced glycation end products (AGEs) which deposit, inter alia, in intervertebral discs. AGEs can bond with receptors on the surface of cells and affect intracellular processes. This leads, among other things, to the activation of protein kinase activated by mitogens (MAP kinase), which in turn causes activation of the nuclear transcription factor (NF-k $\beta$ ), which influences the expression of genes coding metalloproteinases of the extracellular matrix -2 (MMP-2). MMP-2 hydrolyses peptide bonds in type I, II and III collagen, one of the main components of the nucleus pulposus. This may result in earlier degeneration of intervertebral discs in the low back, and pain [22]. Our respondents with type 2 diabetes had a 2.5-times greater chance of developing recurring NSLBP in comparison with the other respondents, in the univariate logistic regression model $(O R=2.519 ; p=0.001)$ (Table 3$)$.
Nevertheless, Altinel et al. came to different conclusions. They conducted a study in a group of 2,035 Turkish residents and did not find any relationship between type 2 diabetes and the occurrence of low back pain incidents [38].

Killians and Mc Michael have reported that proinflammatory cytokines, which participate in the allergic cascade, inter alia, tumour necrosis factor (TNF)- $\alpha$, interleukin (IL)- 1 , interleukin (II)- 6 as well as prostaglandins (PG)- $E_{2}$ and neuropeptides, may stimulate the development of an inflammatory response (in the intervertebral discs of the lumbosacral section of the spine affected by degenerative processes), which becomes the decisive factor in the creation of discogenic pain. Apart from that, histamine, in high concentrations, may irritate nociceptors, inter alia, in the area of the annulus fibrosus of an intervertebral disc [18]. The existence of a relationship between allergy and the occurrence of low back pain incidents has been confirmed by a study carried out in Australia in which over 8,000 women took part [21].

Beeckmans et al. conducted a review of original papers published in the Medline database between January 1950 and January 2016 in order to determine the potential relationship between NSLBP and respiratory tract inflammations, asthma, chronic obstructive lung disease, allergy and chronic sinusitis. The existence of such a relationship was demonstrated for allergy, asthma and respiratory tract infections [15]. In our subjects suffering from allergies, the probability of the occurrence of recurring NSLBP was 2 times greater in comparison with the other respondents, in the univariate logistic regression model $(O R=$ $2.022 ; p<0.05)$. We did not confirm the existence of such a relationship for chronic diseases of the respiratory system (asthma, chronic obstructive lung disease, bronchiectasis) (Tables 3, 4).

\section{Limitations of the study}

A limitation of our study was the fact that the information on chronic diseases of the respondents had been acquired from their interviews and not from physical examinations.

\section{Conclusions}

In the concluding remarks it should be emphasised that the issue of recurring NSLBP applies not only to older age groups, but also young adults. Therefore, prevention programmes aimed at the prevention of recurrences of NSLBP should also include this age group. Both nurses and paramedics are professional groups exposed in a special way to the occurrence of NSLBP [9]. However, the results of our study prove that the nature of professional work, associated with considerable biomechanical load on the spine, is not the only risk factor of recurrences of NSLBP. Therefore, a holistic approach of the family doctor to a patient with recurring NSLBP plays an important role in the diagnostic and therapeutic process. It should take into account not only the physical factors connected with professional work, but also the patient's lifestyle and their concurrent diseases. Thus, the family doctor's tasks should include accurate collection of individual elements of the patient's lifestyle in the interview. Educational activities aimed at this group of patients should include not only popularisation of rules of respect for the spine's biomechanics/avoidance of overloading positions, but also propagation of a healthy mode of life as an important factor in the prevention of recurrences of NSLBP. It is necessary to conduct further research on the impact of chronic diseases on the occurrence of recurring NSLBP. Evidence for the existence of new predictors may be a basis for developing better prevention strategies. 


\section{References}

1. Kozinoga M, Majchrzycki M, Piotrowska S. Low back pain in women before and after menopause. Prz Menopauzalny 2015; 14(3): 203-207.

2. Kucharz EJ, Mastalerz-Migas A, Kwiatkowska B, et al. Inflammatory low back pain: diagnostic and therapeutical recommendations for family doctors. Fam Med Prim Care Rev 2016; 18(3): 399-407.

3. Raciborski F, Gasik R, Kłak A. Disorders of the spine. A major health and social problem. Reumatologia 2016; 54(4): 196-200.

4. Brunner F, Weiser Sh, Schmid A, et al. Non-specific low back pain. In: Boos N, Aebi M, eds. Spinal disorders. Fundamentals of diagnosis and treatment. New York-Berlin-Heidelberg: Springer-Verlag; 2008: 585-602.

5. Elfering A, Mannion AF. Epidemiology and risk factors of spinal disorders. In: Boos N, Aebi M, eds. Spinal disorders. Fundamentals of diagnosis and treatment. New York-Berlin-Heidelberg: Springer-Verlag; 2008: 153-174.

6. Martyniuk A, Górski S, Górska A. Bóle w odcinku lędźwiowo- krzyżowym kręgosłupa - istotny i narastający problem u dzieci i młodzieży. Przegląd piśmiennictwa. Probl Pielęg 2016; 24(1): 69-73 (in Polish).

7. Hoy D, March L, Brooks P, et al. The global burden of low back pain: estimates from the Global Burden of Disease 2010 study. Ann Rheum Dis 2014; 73(6): 968-974.

8. Adams MA, Bogduk N, Burton K, et al. The biomechanics of back pain. $2^{\text {nd }}$ ed. London: Churchill Livingstone; 2006.

9. Hurwitz E, Shekelle P. Epidemiology of low back pain disorders. In: Morris CE, ed. Low back pain syndrome. Integrated clinical management. New York: Mc Graw-Hill; 2005: 83-118.

10. Heneweer H, Vanhees L, Picavet HS. Physical activity and low back pain: a U-shaped relation? Pain 2009; 143(1-2): 21-25.

11. Heuch I, Heuch I, Hagen K, et al. Is there a U-shaped relationship between physical activity in leisure time and risk of chronic low back pain? A follow-up in the HUNT Study. BMC Public Health 2016; 16: 306, doi: 10.1186/s12889-016-2970-8.

12. Noll M, de Avelar IS, Lehnem GC, et al. Back pain prevalence and its associated factors in Brazilian athletes from public high schools: a cross-sectional study. PLoS One 2016; 11(3): e0150542, doi: 10.1371/journal.pone.0150542.

13. Nuwayhid IA, Stewart W, Johnson JV. Work activities and the onset of first-time low back pain among New York fire fighters. Am J Epidemiol 1993; 137(5): 539-548.

14. Kraemer J, Hasenbring M, Kraemer R, et al. Discosis. In: Kraemer J, Hasenbring M, Kraemer R, et al., eds. Intervertebral disc diseases. Causes, diagnosis, treatment and prophylaxis. $3^{\text {rd }}$ ed. New York: Thieme Stuttgart; 2008: 43-58.

15. Beeckmans $\mathrm{N}$, Vermeersch $\mathrm{A}$, Lysens $\mathrm{R}$, et al. The presence of respiratory disorders in individuals with low back pain: a systematic review. Man Ther 2016; 26: 77-86.

16. Eisenstein SM, Engelbrecht DJ, Masry WS. Low back pain and urinary incontinence. A hypothetical relationship. Spine 1994; 19(10): 1148-1152.

17. Kauppila LI. Atherosclerosis and disc degeneration/low back pain - a systematic review. Eur J Vasc Endovasc Surg 2009; 37(6): 661-670.

18. Killian S, Mc Michael J. Seasonal allergy induced back pain: a report of two cases. J Allergy Disord Ther 2015; 2: 004.

19. Leino-Arjas P, Solovieva S, Kirjonen, et al. Cardiovascular risk factors and low-back pain in a long-term follow-up of industrial employees. Scand J Work Environ Health 2006; 32(1): 12-19.

20. Schneider S, Mohnen SM, Schiltenwolf M, et al. Comorbidity of low back pain: representative outcomes of a national health study in the Federal Republic of Germany. Eur J Pain 2007; 11(4): 387-397.

21. Smith MD, Russell A, Hodges PW. Do incontinence, breathing difficulties and gastrointestinal symptoms increase the risk of future back pain? J Pain 2009; 10(8): 876-886.

22. Tsai TT, Ho NY, Lin YT, et al. Advanced glycation end products in degenerative nucleus pulposus with diabetes. J Ortop Res 2014; 32(2): 238-244.

23. Kuorinka I, Jonsson B, Kilbom A, et al. Standardised Nordic questionnaires for the analysis of musculoskeletal symptoms. Appl Ergon 1987; 18(3): 233-237.

24. Bączkiewicz M, Demczuk-Włodarczyk E. Validation of the questionnaire for adolescents concerning ailments of lumbosacral region. Przegl Epidemiol 2011; 65: 123-128.

25. Biernat E, Stupnicki R, Gajewski K. Międzynarodowy Kwestionariusz Aktywności Fizycznej (IPAQ) - wersja polska. Wych Fiz Sport 2007; 51(1): 47-54 (in Polish).

26. Paffenbarger RS Jr, Hyde RT, Wing AI. Physical activity and physical fitness as determinants of health and longevity. In: Bouchard C, Shephard RJ, Stephens TS, et al., eds. Exercise, fitness and health. Champaign (IL, USA): Human Kinetics Publishers; 1990: 33-48.

27. Krismer M, van Tulder M. The Low Back Pain Group of the Bone and Joint Health Strategies for Europe Project. Strategies for prevention and management of musculoskeletal conditions: low back pain (non-specific). Best Pract Res Clin Rheumatol 2007; 21: 77-91.

28. You DC, Kim YS, Ha AW, et al. Possible health effects and caffeinated coffee consumption on Alzheimer's disease and cardiovascular disease. Toxicol Res 2011; 27(1): 7-10.

29. Banks S, Dinges DF. Behavioral and psychological consequences of sleep restriction. J Clin Sleep Med 2007; 3(5): 519-528.

30. Furtado RNV, Ribeiro LH, de Arruda Abbo B, et al. Nonspecific low back pain in young adults. Rev Bras Reumatol 2014; 54(5): 371-377.

31. Domżał TM. Przewlekłe nieswoiste bóle krzyża - stara dolegliwość czy nowa choroba neurologiczna? Pol Prz Neurol 2007; 3(4): 216-227 (in Polish).

32. Stodolny J. Choroba przeciqżeniowa kręgosłupa. Kielce: ZL Natura; 1999 (in Polish).

33. Iwahashi M, Matsuzaki $\mathrm{H}$, Tokuhashi $\mathrm{Y}$, et al. Mechanism of intervertebral disc degeneration caused by nicotine in rabbits to explicate intervertebral disc disorders caused by smoking. Spine (Phila Pa 1976) 2002; 27(13): 1396-1401.

34. Uematsu Y, Matuzaki H, Iwahashi M. Effects of nicotine on the intervertebral disc: an experimental study in rabbits. J Orthop Sci 2001; 6(2): 177-182.

35. Hangai M, Kaneoka K, Kuno S, et al. Factors associated with lumbar intervertebral disc degeneration in the elderly. Spine J 2008; 8(5): $732-740$

36. Kostova V, Koleva M. Back disorders (low back pain, cervicobrachial and lumbosacral radicular syndromes) and some related risk factors. J Neurol Sc 2001; 192(1-2): 17-25.

37. Starzyk K, Wożakowska-Kapłon B. Objawy mięśniowe w przebiegu stosowania statyn - fakty, mity, rzeczywistość i stanowiska ekspertów. Folia Cardiol 2015; 10(5): 354-360 (in Polish).

38. Altinel L, Köse KC, Ergan V, et al. The prevalence of low back pain and risk factors among adult population in Afyon region, Turkey. Acta Orthop Traumatol Turc 2008; 42(5): 328-333 (in Turkish). 
Tables: 4

Figures: 0

References: 38

Received: 29.04.2017

Revised: 02.06.2017

Accepted: 19.06.2017

Address for correspondence:

Anna Citko, MD

ul. Pogodna $29 \mathrm{C} / 22 \mathrm{~A}$

15-365 Białystok

Polska

Tel.: +48 516 729-560

E-mail: anka234@gmail.com 